\title{
Niklas Luhmann
}

Niklas Luhmannt 1968-ban nevezték ki szociológia professzornak az újonnan megalapított Bielefeldi Egyetemen. Megkérdezték tőle, milyen témán kíván majd dolgozni. Így válaszolt: "A modern társadalom elméletén. Időtartam 30 év, költség nincs.” Ezek után pontosan ezt az elméleti programot valósította meg. 1998 decemberében bekövetkezett haláláig, 70 éves koráig több mint 14.000 nyomtatott oldalnyi munkát publikált.

\section{Szerzői információ:}

\section{Gotthard Bechmann}

Frankfurtban és Berlinben végezte jogi, politológiai, szociológiai és pszichológiai tanulmányait. 1973-tól a Frankfurti Egyetem kutatója. 1984-tôl a Karlsruhei Kutatóközpont (ITAS) tudományos munkatársa. Vendégelőadóként dolgozik a Brémai, Moszkvai, Tamperei és San Sebastiani Egyetemeken. Tagja a Karlsruhei Egyetemen múködő Fenntartható Fejlôdés és Technológiai Akadémia bizottságának. Alelnöke a Globális Problémák és a Fenntartható Fejlódés Nemzetközi Intézetének (Moszkva). Eddig megjelent publikációiban elsôsorban a kockázati kommunikáció és a rizikó társadalmi hátterével foglakozik. Legutolsó munkái: Bechmann,G ./Hronszky, I. (eds): Expertise and ist Interface. Berlin 2003; Bechmann,G./Krings,B-J./Rader,M. (eds): Across the Divide. Berlin 2003.

\section{Nico Stehr}

A Karlsruhei Kutatóközpont munkatársa, a tudástársadalom nemzetközileg elismert teoretikusa. Kutatási területei: a modern társadalmak átalakítása ismereti társadalmakká; az éghajlat és a társadalom közti összefüggések; a modern gazdaság társadalmi alapjai; a társadalom- és természettudományi ismeretek felhasználása. Folyóiratunk 2002/3-as számában megjelentettük „The Fragility of the Modern Societies” c. könyvének egy fejezetét.

Legújabb munkái: The Governance of Knowledge (A tudás szabályozása) Transaction Books, 2003 és Wissenpolitik (Tudáspolitika) Suhrkamp Verlag, 2003.

\section{Így hivatkozzon erre a cikkre:}

Bechmann, Gotthard, Nico Stehr. „Niklas Luhmann”.

Információs Társadalom II, 4. szám (2002): 20-33.

https://dx.doi.org/10.22503/inftars.II.2002.4.2

A folyóiratban közölt müvek

a Creative Commons Nevezd meg! - Ne add el! - Így add tovább! 4.0

Nemzetközi Licenc feltételeinek megfelelően használhatók. 


\section{Gotthard Bechmann, Nico Stehr Niklas Luhmann}

\section{Bevezetés}

Az európai újságokban és magazinokban 1999-ben megjelent számos nekrológ közül némelyik úgy emlékszik Niklas Luhmannra, mint a 20. század legjelentôsebb társadalomteoretikusára. Ennek ellenére, neve az angolszász világban szinte teljesen ismeretlen a társadalomtudomány szakemberei között.

Luhmann középosztálybeli családban született a németországi Lüneburgban 1927. december 8-án. A középiskola után (Notabitur) a hadsereg kötelékében az amerikai haderốk fogságába került. 1946-49-ig jogot tanult Freiburgban, majd köztisztviselő lett és tíz évig dolgozott Hannoverben, mint adminisztrációs ügyvéd. 1962-ben ösztöndíjat nyert a Harvardra és egy évet töltött Talcott Parsons mellett. 1968-ban kinevezték a szociológia professzorának az újonnan megalapított Bielefeldi Egyetemen, ahol nyugalmazásáig tevékenykedett. Röviddel kinevezése elốtt megkérdezték tôle, hogy milyen témán kíván dolgozni az egyetemen. Így válaszolt: „A modern társadalom elméletén. Időtartam 30 év, költség nincs.” Ezek után pontosan ezt az elméleti programot valósította meg. 1998 decemberében bekövetkezett haláláig, 70 éves koráig több mint 14.000 nyomtatott oldalnyi munkát publikált.

Luhmann útja a modern társadalomról alkotott elmélet felé kettôs megközelítésbôl indul ki: az 1960-as évek végétốl kezdve elôször esszék formájában, majd az 1980-as évektől inkább monográfiákat írt, amelyek a társadalom különböző intézményeivel (jog, tudomány, mûvészet) foglalkoztak. Luhmann intellektuális fejlődése 1997-ben tetôzött, magnum opus-a, „A társadalom társadalma” címú mû megjelenésével. Aki redundanciát és ismétlést gyanít a címből, az elsố ránézésre úgy érezheti, hogy szkepticizmusa alátámasztott. Ez a kétkötetes munka nem tartalmaz új témákat, korábban publikálatlan megközelítéseket még kevésbé. Ennyiben inkább kiegészítés, összegzés, mint előrelépés egy új területre. Mindazonáltal egy második, figyelmesebb áttekintés után sok minden feltárul az olvasó előtt. Az esszékkel ellentétben, amelyek idônként kísérleti jellegúek, sốt hangvételükben játékosak és alkalmanként kérdôjellel zárulnak, a könyvforma már sokkal rendszeresebb bemutatást igényel. „A társadalom társadalma" a végső kő elméleti katedrálisában, és térképet, útmutatást nyújt a modern rendszerek elméletének megértéséhez.

E főmû köré csoportosulnak korábbi egyedi elemzései: „A társadalom tudománya”, „A társadalom közgazdaságtana”, „A társadalom művészete”, „A társadalom joga” és két posztumusz kiadott könyv: „A társadalom politikája” és „A társadalom vallása”. Ezen elemzések sorozatának bevezetôje egy 674 oldalas könyv, címe „Társadalmi rendszerek: egy általános elmélet körvonala”. Ez a mú még mindig a legsúrítettebb, absztrakt, és - ha az ember veszi a fáradtságot, hogy utat törjön rajta keresztül - a legkielégítốbb megjelenítése az elmélet magjának. 
Immár rendelkezésünkre áll egy kezdeti általános kép. Ha az ember teljességében akarja látni Luhmann munkásságát, ki kell ismernie magát általános megközelítésének architektúrájában. Ezeken - a rendszerekről szóló tanulmányokon - kívül Luhmann még publikált kevésbé terjedelmes, sorozatnyi szociológiai és történelmiszemantikai elemzéseket is: a „Társadalmi struktúra és szemantika” négy kötetét és a „Szociológiai felvilágosodás” hat kötetét. Ezek a tanulmányok Luhmannt univerzális tudósként mutatják be, aki elméletét a felvilágosodás és az európai filozófia kontextusába helyezi. Ettốl a messzire nyúló kutatástól függetlenül egy sor politikai és társadalmi elemzést is publikált a modern társadalomról, súlyos közösségi problémákat kommentálva. Itt csak néhány könyvet említünk: „A kockázat szociológiája”, „Ökológiai kommunikáció”, „A tömegmédia valósága” és „A jóléti állam politikai elmélete”. Összesítve, munkája mintegy 700 publikációból és számtalan angol, francia, olasz, japán, orosz és kínai fordításból áll.

Luhmann életmúvében sưrún utal George Spencer Brown és a radikális konstruktivizmus operatív logikájára. Ezeket összegzô módon kezeli ahhoz, hogy egy sor így nyert metodológiai eszközzel ellátva felvázolhassa társadalmi szuper-rendszerekről szóló elméletének tervezetét és konceptuális struktúráját. A politika, a vallásszociológia, a mûvészetszociológia, és az erkölcsszociológia elméleteit ezt követôen fejleszti ki.

Niklas Luhmannt ábrázoló rövid intellektuális portrénkban elôször szándékosan összpontosítunk társadalomelméletének lényegére, különösen utolsó publikációjában található gondolataira. Tartózkodunk egy tudásszociológiai nézőpont előterjesztésétốl, amely megkísérli megragadni pl. az angolszász társadalomtudomány vonakodását attól, hogy Luhmann eszméivel olyan erốteljesen és kiemelkedốen foglalkozzék, ahogy azt nemcsak saját hazájában, de Olaszországban, Franciaországban, és sok más nem angol nyelvű társadalomban is tették. Ez egy olyan történet és kihívás, amit egyelőre válasz nélkül hagyhatunk. Másodszor, miután felvázoltuk Luhmann újszerú rendszerelméleti megközelítésének fő vonásait, különböző kritikai megfigyeléseket és megjegyzéseket kínálunk.

Luhmann számára a társadalmi differenciálódás és a rendszerformálódás a modern társadalom alapvető sajátossága. Ez azt is jelenti, hogy a rendszerelmélet és a társadalomelmélet kölcsönösen függenek egymástól. Ezen feltételek szerint egy társadalom nem a folyamatban levố interakciók összessége, hanem inkább egy magasabbrendű, más típusú rendszer, amit a rendszer és a környezet közti elkülönülés határoz meg; és épp ez az elkülönülés a témája Luhmann kétkötetes „A társadalom társadalmá"-nak.

Luhmann kulcsfontosságú üzenete: a szociológia végsố soron a társadalom egy elmélete, vagyis nem természettudomány. Ha visszatekintünk a szociológia történetére, semmi esetre sem magától értetôdô. Ellenkezôleg, a múlt század kezdetén - és különösen 1945 után Németországban és máshol - a szociológia a társadalommal való kapcsolatának leplezésével határozta meg identitását. Főleg társadalmi entitások elmélete volt, olyan kategóriákkal, mint szerepek, interakció, szándék és társadalmi cselekvés, amelyek kialakították az alapvetố konceptuális keretet egy olyan szociológiához, amely egyre empirikusabbá vált és elméletileg hajlott a természettudományok modelljének követésére, az ok-okozatiságot és a törvények felfedezését hangsúlyozva. 
A társadalom koncepciója viszont megórizte holisztikus jellegét; amit például a kritikai elmélet elszántan védett, Jürgen Habermas pedig a kommunikatív okság elméletévé fejlesztett. Ez az igény összeütközött a szociológiának azzal a felfogásával, mely szerint az, a társadalmi entitások egyetemes és független elmélete. Vajon a szociológiában általánosan elfogadott nézôpont a társadalom-egészt olyan társadalmi rendszerré változtatná, mint bármelyik másik, ám ugyanakkor egy mindent felölelő és fundamentális rendszerré? A szociológia a mai napig képtelen volt ebbôl az ellentmondásból kitörni, és ezt elfojtással és historicizálással ellenpontozta: a társadalomelmélet, különösen a kritikai társadalomelmélet jórészt a filozófia diszciplináris megfontolásaira maradt, amely az általános vélekedés szerint a végsô, alapvetố gondolati struktúrák és a világhoz való viszony holisztikus megragadásának specialistáival rendelkezik. Ha a társadalomtudósok a társadalom elméletével foglalkoztak, akkor azt jellemző módon a klasszikusok szövegmagyarázatával tették, mintha saját tudományáguk története rendelkezne az alapfelvetések megtartásának és elôhívásának képességével.

Ma úgy tűnik, hogy a társadalom kizárása a szociológiából bosszút követel. Mint Max Weber isteneinek elfojtott világa - akik a modern világba való visszatérésüket az értékek szüntelen konfliktusának formájában ünneplik - a társadalom koncepciója ma a fogalmak nagy tarkaságában tér vissza, mint „poszt-indusztriális társadalom” (Bell), ,a kockázat társadalma” (Beck), „a tudás társadalma” (Stehr), és „poszt-modern társadalom" (Lyotard); mintha a társadalom egyetlen aspektusa képes volna az egész helyébe beállni. Ilyen ad hoc terminológiai fabrikációk megmutatják, hogy mi is van elfojtva - konkrétan a társadalom egészként való felfogásának igénye.

Tehát mit is jelent ez pontosan a szociológia számára - kérdezi Luhmann -, ha el kívánjuk kerülni a naiv objektivizmus csapdáját, amely a társadalmat úgy tekinti, mint egy adott tárgyat, amely ténylegesen megelőz minden tudományos megfigyelést? Az objektív nézôpont implikációja az, hogy a társadalmat egy társadalmon kívüli pontból kell megvizsgálnunk. Nincs ilyen pont. A tudomány és a társadalom egyaránt a társadalmi valóság kifejezôdései. Ez pontosan az a pont, ahol például a klasszikus tudásszociológia kifulladt. Kénytelen volt a tudás megfigyelését egy hipotetikus, szabadon lebegố intelligenciára átruházni, amely az észlelés - semmiféle érdekek vagy ideológiák általi - torzulásának nem volt kitéve. Újabban számos nézôpont fogadta be a gondolatot, hogy az észlelés aktusa önmagában mindig egy mozzanat az észlelés teljességében. Luhmann osztja ezt a megközelítést - és ugyanakkor tovább is megy, azt állítva, hogy nem létezhet olyan „társadalom”, amely d független megfigyelés számára tárgyként megközelíthetố lenne.

Mihelyt megszúnünk úgy tekinteni a társadalmat, mint csupán a kutatásnak valamely szociológiai tárgyát, és ehelyett múködési jellegzetességére összpontosítunk, mint magának a szociológiai észlelés lehetőségének a feltételére, akkor a szociológia olyan témává válik, amely önmagával ugyanabban az értelemben foglalkozik, ahogy a filozófia a reflexióról beszél. Luhmann átviszi a szubjektum ön-referenciális múködési módját a társadalmi rendszerek elméletébe. Ugyanakkor válaszol a kérdésre: Hogyan lehet gyakorolni a szociológiát mint a társadalom olyan elméletét, amely nem szû́ri ki elő́re az elmélet és az alany közti kapcsolatot? Ez Luhmann szerint megköveteli az olyan episztemológiai pozíciók kiiktatását, amelyek az alany-tárgy paradigma dichotómiáján alapulnak. A szociológia szembesül a társadalommal mint alannyal. 
Luhmann ezért amellett érvel, hogy ez olyan tulajdonságok kutatását igényli, amelyeket mindig is önmaga generált. Luhmann következetesen posztulálja a társadalom radikálisan anti-humanista, non-ontologikus és radikális-konstruktivista elképzelését.

Luhmann érett elméleti megközelítésének legradikálisabb feltevése a különbségekre fektetett hangsúly - pontosabban a megkülönböztetésekre, amelyek már nem objektív különbségeknek tû́nnek, hanem konstrukcióknak. Az alany koncepciójának behelyettesítése és az alany/tárgy különbségtétel átvitele a rendszer és a környezet közti megkülönböztetésbe Luhmannt a társadalom poszt-ontologikus elméletéhez vezeti, amely naturalisztikus és empirikus alapokon fejlődött ki, mint a megfigyelés elmélete. A modern filozófiának ez az alapvetô rákérdezése az alanyra, valamint a természettudományok és a bölcselet következésképpeni megkülönböztetése - és ezzel együtt a társadalmat definiáló humanisztikus-antropocentrikus elmélet elvetése - Luhmann megközelítésének sok kritikáját váltotta ki, és még több értetlenséget vele szemben.

\section{Luhmann rendszerelméletének származástana}

A rendszer koncepciója Luhmann alapvető kiindulópontja. Ebből a szempontból elüt a német szociológiától, amely legalábbis Max Weber óta fóleg cselekvéselmélet volt. Ezt a kategorikus törést bizonyára leginkább az interakciók, a szervezetek vagy társadalmak, mint „rendszerek” társadalmi jelenségeinek leírására vonatkozó javaslatai jelzik. Rendszerekben gondolkodni először is azt jelenti, hogy „már nem tárgyakról beszélünk, hanem különbségekrôl, sốt, hogy a különbségeket többé nem létezô tényeknek (megkülönböztetéseknek) tekintjük, s létrehozásukhoz inkább visszatérünk egy imperativuszhoz, mivel az ember másként nem tudna semminek se nevet adni, így nem lenne semmi megfigyelni való sem és semmit se lehetne folytatni" (Luhmann, 1997:60).

A „társadalmi” szövege (mint minden más szöveg) nem önmagyarázó, és nincs különálló írásokban letétbe helyezve sem. Nincs semmilyen következetes jelentése, ami megegyezik önmagával, és amelyet vissza lehetne vezetni megalkotásának egyetlen konkrét pillanatához. A szociológiának keményen kell munkálkodnia anélkül, hogy tárgyainak körét egyetlen halom dologként foghatná fel, a meghatározott formával rendelkezố tényekhez hasonlóan - amelyek kölcsönös kapcsolata ráadásul egy egységes elv által volna biztosítva (legyen az a természet, isteni akarat, erkölcs vagy egy transzcendentális alany). A modernizmus metafizikai körülményei között a megfigyelố számára többé nem érhetố el egy olyan meta-perspektíva, amely megengedi olyasvalaminek a felismerését, ami a természetesre mint a változatlan lényegre, vagy a társadalom totalitására emlékeztetne.

Luhmann rendszerelméleti megközelítése szerint a világ (mint a lehetséges leírások horizontja) olyan kontingens megkülönböztetések és címkék hálózatának eszköze által fejeződik ki, amelyeket mindig kontextuson belül kell érteni. Hogy a megfigyelố ezt úgy címkézi mint ez, (és nem mint az), annak a megkülönböztetésnek köszönhető, amely szerint mindkét momentum, egymástól elválasztva, csak egymáshoz való kapcsolatuk fényében érthető meg; a megkülönböztetett egységek csak a másiktól való különbözôségükben rendelkeznek saját identitásukkal. Ahhoz, hogy valamit 
- mint vạlami - tudjunk jellemezni, előre meg kell különböztetnünk azt a tôle különböző másiktól: ami például érdemes arra, hogy igaznak nevezzük, azt a látszattól való különbséggel mérjük; a múltról való beszéd pedig csak egy olyan jelenre való utalással nyer értelmet, amely jelen (alkotóan) megkülönböztethetô tôle. Még ha nem is vetődik fel nyíltan témaként, ez a másik oldala az ennek, vagy annak nevezett valaminek: mindig minden szó- vagy gesztusbeli döntésünkben jelen van. Ez egy állandó horizont. Bármikor lehetséges oldalt változtatni és a forma megkülönböztetett momentumát (látszat után az igazságot, jelen után a múltat) a figyelem középpontjába hozni, és azt a további döntések kiindulópontjává tenni. Önmagunk és a világ szándékos feldolgozásának érdekében elkerülhetetlen, hogy megkülönböztessünk és címkézzünk. Ezek a műveletek minden érzékelés és felismerés kezdetei.

Hogy egy bizonyos kontextusban miért egy bizonyos módon vannak megkülönböztetve és címkézve a dolgok és nem másként, azt lehetetlen meghatározni a rendszerelmélet perspektívájából. A megkülönböztetés mindig előre megfontolt szándék nélkül és előzetes meghatározatlanságban történik, és mindegyik formát ellátja a kitörölhetetlen esetlegesség pecsétjével: elvben az ember teljesen más megkülönböztetéseket is tehetett volna. Tehát rendszerekrôl beszélni azt jelenti, hogy megállapítunk egy különbséget: a rendszer és a környezet közti különbséget.

Rendszer alatt Luhmann egymáshoz kapcsolódó események sorát érti, vagy kapcsolódó múveletek sorát. Élólények esetében például ezek fiziológiai folyamatok; pszichés rendszereknél elképzelések; és társadalmi kapcsolatok esetében a kommunikáció. A rendszer úgy alakul ki, hogy megkülönbözteti magát olyan esemény- és mûvelet-környezettől, amelyeket nem lehet belsố struktúrájába integrálni.

Korai mentorával, Talcott Parsons-zal ellentétben, aki a rendszereket kollektívan megosztott normák és értékminták jelenléte alapján definiálta, Luhmann egy szigorúan relációs módon kialakított rendszerkoncepcióból indul ki. Elképzelését egy olyan lényegi határ gondolatára alapozza, amely megengedi a belül és kívül közti megkülönböztetést. Egy rendszer minden egyes múvelete (társadalmi rendszerek esetében: minden egyes kommunikáció) (re)produkálja ezt a határt azáltal, hogy beágyazódik további múveletek egy hálózatába, amelyben ugyanakkor megtalálja saját egységét/identitását. Tehát a határnak ilyen koncepcióját - mindenek felett pszichés és társadalmi rendszerekkel kapcsolatosan - nem térbelileg, hanem operatívan kell érteni: „A rendszer határa nem más, mint a rendszert egyénítô múveletek típusa és öszszeállása. A rendszer formája az, amelynek a másik oldala így a környezet lesz" (Luhmann, 1997:76-77.). Ez az operatív értelem azt a belátást igényli, mely szerint a rendszerek képtelenek túllépni saját határaikat.

Ez a fajta kutatási stratégia a társadalmi rend kialakulásának valószínútlenségérôl való elemi meggyőzôdés következménye. Elvben minden lehetne egészen más. Luhmann szemszögébốl a társadalmi struktúrák számára nincs semmi ön-evidens: igénylik az állandóan új társadalmi értelmezést saját létük és meghatározott formájuk szempontjából. A parsonsi meggyőződés funkcionalizmusával ellentétben Luhmann nem kötelezi el magát a társadalmi rendszerek állandósága mellett. Ellenkezóleg, a társadalminak az esetlegessége és összetettsége minden elméleti munkásságának kiindulópontja.

Luhmann elméletének összetettsége nemcsak azoknak a társadalmi témáknak a sokféleségén keresztül fejeződik ki, amelyeket sikerül megoldania a rendszerelméleti megközelítés segítségével, hanem oly módon is, hogy a perspektívák hangsúlya 
eltér, valahányszor bemutatja általános elméleti megközelítését. A Társadalmi Rendszerek címû́ munkáját elsốsorban a rendszer és a környezet közti megkülönböztetés szempontjából írta, míg A társadalom tudománya a megfigyelhető rendszerek elméletét veszi kiindulópontul, ami további episztemológiai vitákhoz vezet a megfigyelés megfigyeléséról. Ha választanunk kellene egy ilyen központi perspektívát A társadalom társadalmához, a hangsúly egyértelmúen a társadalmi rendszeren lenne, ellentétben minden társadalmi alrendszerrel, melyet a társadalmon belüli társadalmi múködések alakítanak ki.

\section{A különbségek különbsége}

Luhmann elhatárolja magát attól, amit „régi európai” ontologikus elméleti hagyománynak nevez, és amelynek potenciálja a modern társadalom egész összetettségében való megragadására reménytelenül idejétmúlt. Elhatárolódása által megpróbál túllépni kétezer évnyi hagyományon, amelyet, szerinte, immár meghaladott a funkcionális megkülönböztetés eljárása. Úgy írja le a gondolkodás régi európai stílusát, mint ami a különbözôség alatt megbújó egység azonosításával foglalkozik. A klasszikus meglátás szerint a társadalom cselekvő alanyokból áll, akiknek alapvető egysége kölcsönös megértésen alapszik. Az ontológia utal egy objektívan létező világra, amely elkülönül az ố tudatában levố alanyoktól, akik képesek egyértelmú nyelvi reprezentációjára.

Luhmann ezzel szembeállít egy olyan világlátást, amely időbelivé tesz, megkülönböztet és decentralizál minden identitást. Az identitások múltbeli események termékei. Az elmélet végső referenciapontja többé nem az egység. Azáltal, hogy Luhmann még a létezés/nemlétezés ontológiai sémáját is relativizálja - mint csupán egyet a sok megfigyelési séma közül, jelentôs gondolkodási hagyományok alapjait támadja meg. Luhmann szerint az ellentmondás az, hogy a régi európai hagyomány egy olyan társadalomból nőtt ki, amely ma már nem létezik, sem a kommunikációs rendszer szempontjából, sem a megkülönböztetés formáinak értelmében.

Ez a hagyomány még így is szerves alkotórésze marad történelmi örökségünknek, és ilyen értelemben az orientáció szempontjából releváns kultúra része. Nem tûnhet el, csak mert többé nem felel meg; állandóan negálódik, és ezért szükséges az elérhetôsége.

Itt egy másik alapvető megkülönböztetés tûnik fel, amelyet Luhmann társadalomelméletének strukturálására használ: konkrétan a társadalmi struktúra és a szemantika közti megkülönböztetés. Jellemzô, hogy ez a megkülönböztetés magában foglalja önmagát, maga is egy szemantikai megkülönböztetés, és a probléma pontosan ennek az ellentmondásnak az eredményes kibogozása. A társadalomelmélet két szinten helyezkedik el: szemantikai szinten megkülönböztetett a régi európai hagyománytól, míg társadalmi strukturális szinten az evolúcióra, a megkülönböztetésre és a média fejlődésére utal. 


\section{Emberek nélküli társadalmak}

Luhmann három premisszát vezet be társadalomanalízisébe, amelyek nemcsak heves kritikát, de széleskörú félreértést is váltottak ki egészen odáig, hogy antihumanista és cinikus érveléssel vádolták meg: (1) A társadalom nem emberekbôl áll. A személyek a társadalom környezetébe tartoznak. (2) A társadalom egy autopoietikus rendszer, amely kommunikációból áll és semmi másból. (3) A társadalmat csak mint világtársadalom lehet megfelelően megérteni.

Az emberek számúzése a társadalom környezetébe a humanista kozmológia decentralizációjának betetôzése. Az, hogy az emberiség mostanra Luhmann által megszabadult a társadalom kötelékeitól, úgy tûnik, annak a tendenciának a következetes folytatása, melyben elóbb a reneszánsz kilakoltatta a világegyetem központjából, majd Darwin az evolúció kontextusába való helyezésével megfosztotta egyedi eredetétôl, és végül Freud megfosztotta az autonómiától és önkontrolltól. Míg a klasszikus európai hagyomány az emberek és állatok közti megkülönböztetéssel érzéket, értelmet, akaratot, öntudatot és érzéseket tulajdonított az embereknek, addig a szellemi és társadalmi rendszerek feltétlen elválasztása, amellyel Luhmann a homo socialist helyettesíti be, nyilvánvalóvá teszi, hogy a társadalom egy meghatározott, sui generis kialakuló rend, amelyet nem lehet leírni antropológiai értelemben. A társadalom nem rendelkezik az alany jellegével - még nyomatékosan transzcendens értelemben sem, mint végsố alapvetố gondolatok lehetôségének vagy emberi minôségek mechanizmusának feltétele. Nem címezhetők hozzá a cselekvésre szólító emberi felhívások, és semmiképp sem az egyenlôség és igazságosság követelésének illetékes autonóm alanya. A társadalom a végsố elérhetố kommunikatív redukció, amely elválasztja a meghatározatlant a meghatározhatótól, vagy a feldolgozhatót a feldolgozhatatlan összetettségtôl.

Egy részletes elemzésben Luhmann végigköveti a növekvő különbséget az egyén és a társadalom között. Csak miután megtörtént a társadalom és az emberség, emberi természet egyértelmú szétválasztása, lehet látni, hogy mi tartozik a társadalomhoz és mit kell az emberséghez utalni. Ez empirikus - természetes mérésre alapozva nyitja meg az emberség, az emberi öntudat és az emberi agy múködése kutatásának lehetôségét. A társadalmi rendszerek (vagy a társadalom rendszerei) és a fizikai rendszerek szétválásának tézise lehetôvé teszi a társadalom és az emberség közti kapcsolatok világos megértését és követésüket történelmi útjuk során. Ebben az értelemben mindkettő autopoietikus rendszer, az egyik az öntudat alapján, a másik pedig a kommunikáció alapján múködik. De mi a társadalom?

A társadalom, egy kezdeti megközelítésben, az az átfogó társadalmi rendszer, amely magában foglal mindent ami társadalmi, és önmagán kívül semmi társadalminak nincs tudatában. Mindazonáltal minden, ami társadalmi, az kommunikációként van azonosítva. A kommunikáció „egy valóban társadalmi (és az egyetlen egyetemlegesen társadalmi) művelet. Valóban társadalmi oly módon, hogy előfeltételezi az együttmúködő öntudati rendszerek többségét, míg (épp ezért) egy egységként valamely egyéni öntudatnak nem tulajdonítható." Viszont az is igaz, hogy bármi, ami kommunikációt gyakorol, az egy társadalom. Ez messzire ható következményekkel jár. 


\section{A társadalom, mint kommunikáció}

Először, a kommunikáció egy sui generis valóság, ami többé nem tulajdonítható valami másnak. Másodszor, a kommunikáció az a mechanizmus, amely a társadalmat mint autopoietikus rendszert alkotja, és ebben az értelemben dolgozza fel. A kommunikáció negációja maga is kommunikáció, és így a társadalom kifejezése. Harmadszor, ha a kommunikáció autopoietikus reprodukciót jelent, ez azt jelenti, hogy a társadalom egy önmagát helyettesítő rend, ami csak önmagában és önmagán keresztül változhat. A kommunikáció a társadalom alapvetố struktúrájává válik, ahol a kommunikáció és a társadalom közti kapcsolat cirkuláris: nincs kommunikáció társadalom nélkül, nincs társadalom kommunikáció nélkül. De mi a kommunikáció? Vagy egy posztontologikus korszakban többé nem lehet feltenni ilyen kérdéseket?

A legegyszerúbb válasz, hogy a kommunikáció egy mûvelet, pontosan abban az értelemben, ahogy egy megkülönböztetés tétetik. A kommunikatív cselekvések semmit nem mondanak a világról, a kommunikáció pedig semmit nem tükröz a világból, amely tükrözôdés helyett osztályozódik a kommunikáció által. A kommunikáció célja különbségek létrehozása, amelyek aztán további kommunikációhoz kapcsolhatók, alakítva és stabilizálva a rendszer határait. De még maga a kommunikáció sem eredeti, nem a végsố elem, hanem feldolgozó szelekciók szintézise, amelyeket Luhmann információnak, átvitelnek és megértésnek jelöl. E három megkülönböztetô múvelet struktúrája bináris.

Az információ az osztott jelentésból emelkedik ki, amely a gyújtômedencéból annak alapján választható, hogy az átvitelhez vagy az elfelejtéshez tartozik. A kommunikáció cselekvésének megvalósítása annak függvénye, hogy mi van reprezentálva, elfogadva, elvetve, vagy meg nem értve. A társadalmi rendszer felől azt mondhatjuk, hogy az információ tekinthetố külsố referenciának, az átvitel tekinthetô ön-referenciának, a megértés pedig a további kommunikációban a jelentésátvitel feltételének. Ennek a három szelekciónak a szintézise egy ön-referenciális, zárt esemény. Ez lehetôvé teszi, hogy Luhmann rávilágítson a társadalminak az ön-alkotására. Ha az, ami társadalmi, nem több mint kommunikáció, akkor ez azt is jelzi, hogy a társadalmi ebbôl az autopoietikus folyamatból áll, amelynek megvan a saját dinamikája. Akkor a környezet csupán egy inger, nem valódi információforrás. Ennek megfelelően a megértés nem más, mint kommunikatív eseményeknek az ön-referenciális kommunikációs folyamat által létrejött nem önkényes hálózata. Az ismételt diszkusszió azokat az identitásokat alakítja ki, amelyek a határokat alkotják.

A társadalom, vagy amit társadalom alatt korábban értettek a szociológiában, most már felszabadult minden szubsztancionális meghatározástól. Nem egy erkölcsi egység, nem konszenzusra vagy egyéb (bármilyen fajta) racionális integrációra épül; egyedül a folyamatos kommunikáció alakítja. Ennek megfelelő́en nincs értelme olyan megkülönböztetésekrőll beszélni, mint gazdaság/társadalom vagy tudomány/társadalom, miután a politika, a gazdaság és a jog nem tekinthetô a társadalmon kívüli és attól elválasztott valaminek, hanem kommunikatív múveleteikben társadalmi aktusok. Luhmann számára a társadalom tehát azon múveletek teljességéből áll, amelyek nem tesznek különbséget azon tény sajátossága alapján, amely különbséget tesz. Ez másodrangú elméleti státuszba minôsít le minden feltevést a megértésrốl, a fejlôdésrôl, racionalitásról és más célokról. 


\section{A társadalom, mint világtársadalom}

A társadalomnak ebben a harmadik meghatározásában - konkrétan a társadalom, mint világtársadalom definíciójában - Luhmann ismét szándékosan ellentétbe helyezi magát a régi európai hagyománnyal. Elkerüli a társadalom területi meghatározását, amely a társadalom határait a nemzetállamok határaival azonosítja. A globális kölcsönös függések, és az időbeli és térbeli kényszerek felbomlása a modern információs és közlekedési technológiák által, folyamatosan fosztják meg elfogadhatóságától a társadalom területileg korlátolt meghatározását. Egy nemzetközi (inter-nacionális) rendszer vagy egy nemzetek közötti (transz-nacionális) társadalom alternatív koncepciói megbuknak, mert mindazon kulturális megkülönböztetés ellenére, amit hangsúlyoznak, nem jutnak el az ebbốl következô megkülönböztetés egységéhez, és így képtelenek megmagyarázni az ,inter-” vagy a „transz-” jelentését. Ahelyett, hogy a societas civilis findet hagyomány folytatói lennének, pusztán leírják a növekvô sokféleséget, az összetettséget, és az elérhetố opciók növekedését. Ha a világ többé nem értelmezhetô, mint minden látható és közvetlen tárgy gyújteménye, mint aggregatio corporum, akkor mi lesz a józan ésszel, ami lehetővé teszi, hogy világtársadalomról beszéljünk?

Luhmann egy lényegében közhelyes megfigyelésre alapozza elgondolását. A föld végső felderítése, és talán az ûr felderítése, nyilvánvalóvá tette, hogy a világ egy zárt, kommunikatív komplexum. Elvben a földgolyó bármely pontja elérhetô a kommunikáció számára, minden technikai, politikai vagy földrajzi akadály ellenére. A világtársadalom a világ ön-véglegesítése a kommunikációban. Ez a meghatározás akkor nyer létjogosultságot, ha nézetünkben helyet kap a modern társadalomnak a jövőre való létfontosságú összpontosítása. Történelmileg lehetséges megkülönböztetés az egyes területek között, de osztoznak abban, hogy a jövójüket csak egységként lehet tekinteni. A „világ” tehát pontosan ezt a referenciát jelenti a teljesen differenciált funkcionális rendszerek kommunikációs struktúrájában, úgyhogy a „világ” mint az érzékelési élmény teljes horizontja nem aggregátuma, hanem inkább korrelátuma a benne előforduló kommunikatív múveleteknek.

Ismeretelméletileg ennek az elmozdulásnak messzire nyúló vonzatai vannak. A társadalom csak önmagában vizsgálható, és több szempontból is egyetlen egységnek tekinthető anélkül, hogy felbontásán keresztül lehetséges volna eljutni egy „hiteles”, összekapcsoltan megfigyelhetố világhoz. Mindig új megkülönböztetésekhez, új konstrukciókhoz fogunk érkezni. Luhmann számára a megfigyelés elméletének társadalmi-strukturális helye másodlagos. A másodrangú megfigyelés egy megfigyelőnek a világban való elhelyezését jelenti, aki megfigyel másokat, és létrehozza a világ különböző verzióit (beleértve megfigyelônket) - bár ez csak egyetlen világban tehető meg.

\section{Elméletek elméletei}

De hogyan tudja a társadalom önmagát dokumentálni anélkül, hogy önmagával ellentmondásba kerülne, és különösen önmagán kívül álló transzcendentális referenciákhoz való folyamodás nélkül? A társadalom társadalma utolsó fejezetében, „Önmeghatározások" címszó alatt, Luhmann az elmélet és az alany közti bonyolult kapcsolattal foglalkozik. Meg tudja-e az elmélet magyarázni saját helyét a társadalmi fo- 
lyamatban? És ha igen, nem nézi-e a társadalmat bizonyos mértékig kívülról, holott ez csak a társadalmon belül kommunikációs minőségben lehetséges? Itt emlékeztet minket Luhmann (eléggé idevágóan) Escher önmagát rajzoló kezére, amely önmagát és saját képmását is generálja saját művelete során. Luhmann (1997) hasonló úton jár:

Éppúgy, mint az önmegfigyelések, az önmeghatározások (szövegek generálása) is a rendszer egyéni múveletei. Tulajdonképpen a meghatározások és ami meg van határozva nem két külön tárgy, amelyek csak külsôdlegesen kapcsolódnak - egy önmeghatározás esetén, ami meg van határozva, az mindig része annak, ami meghatároz, és megváltozik; azon egyszerủ tény alapján, hogy megjelenik és aláveti magát a megfigyelésnek.

A szociológia tehát mindig a rendszer egységének konstrukciója magában a rendszerben, soha nem érve el ennek a folyamatnak a végét. Ez a belátás arra sarkallja Luhmannt, hogy saját elméletében elkerülje bármiféle következtetés levonását. Bár kifejezetten közeli itt a kapcsolat Hegellel, aki szintén adott az abszolútnak egy ön-referenciális jelleget azáltal, hogy a rendszert teljesen ön-referenciálisnak tekintette - ahol semmi sem lehet külsődleges, mivel minden külsôdleges dolog saját öndifferenciálisának válik egy aspektusává - Luhmann épp ezen a ponton hagyja el ezt a hagyományt azáltal, hogy kibernetikus szókincsre fordítja le és így túljut rajta. De a társadalom nem alany antropológiai-interaktív értelemben sem, ahogy Adorno látta még minden filozófiakritikája ellenére. A társadalom „az emberek közt összeállt kapcsolat”. Az emberi természet nem a társadalom végső eleme, és a társadalmat nem is lehet meghatározni az alany-tárgy klasszikus kognitív modelljén belül; mert a társadalom ön-referencialitása maga okozza e kettôségnek az összeomlását, mivel a megismerés interszubjektív bizonyosságot keres az alany részérôl és stabil tárgyakat előfeltételez. A társadalom azonban nem egy ilyen stabil tárgy.

\section{Kritikai reflexiók}

Luhmann megközelítése szerint csak a radikális konstruktív szemantika nyújt elég távolságot ahhoz, hogy ne kelljen megadni magunk a hagyományos terminológiában rejlő sugalmazásoknak. Luhmann terminológiája munkáinak elméletileg legigényesebb részeiben nélkülözi a klasszikus asszociációkat és konnotációkat. Ha Luhmann tanulmányainak olvasását nem hagyjuk abba pusztán lemondásból, frusztrációból vagy akár haragból, akkor terminológiája jelentôs toleranciát igényel azon olvasóktól, akik nem ismerősek a rendszerelmélet terminológiájában.

Luhmann szigorú, egyszerú mesterséges nyelve nem modorosság, hanem elméleti programjának precizitásából ered - és ennek a programnak tartania kell a távolságot a hagyományos európai társadalomelmélet szemantikájának implikációitól. Ebből a szempontból komolyan kell vennünk a „Társadalmak társadalma” utolsó elótti mondatát, mely szerint a társadalom megfelelố modern elmélete a felismerés és az elméletalkotás önmagában vett kiválósága puszta élvezetének feláldozását követeli.

Ez nem azt sugallja, hogy Luhmann elméletének olvasása egyszerúen küzdés a névleges konstrukciókkal és absztrakt kifejezések zuhatagával; találunk közben elemzéseket a hagyományos európai szemantikáról, ahol Luhmann megkísérli tisztázni, hogy az többé miért nem felel meg a modern társadalom strukturális tényeinek. Újra 
és újra előfordulnak kihegyezett és ellentmondásos leírások, amelyekben az elsőrendû́ megfigyelésrôl másodrendû megfigyelésre való váltás eredményei vannak egy csomóban, mint egy nagyító alatt. Erre jó példa, mikor Luhmann azt mondja az emlékezetrôl, hogy valódi funkciója a társadalomra nézve nem a megőrzés, hanem inkább a feledés; vagy mikor úgy fogja fel az információt, mint a pusztulás terméke, ami frissítése, felülírása során eltúnik.

Ezek a fajta ellentmondások többet jelentenek, mint ügyes szójátékok: bejárati pontokat nyújtanak Luhmann társadalomelméletének konstruktivista magjához, amely abból a tényból áll, hogy minden megfigyelés - olyan mértékben megkülönböztetésekre támaszkodva, amilyen mértékben nem tud reflektálni mint egységes egészre - ellentmondáson alapul. Luhmann szerint a világ egységét mint a társadalom egységét nem lehet megközelíteni mint alapelvet, csak mint egy paradoxont - ez is annak a következménye, hogy a hagyományos szemantika elvesztette jelentését.

De vajon a régi európai szemantika jelentésének elvesztése valóban elkerülhetetlen lenne Luhmannak a „társadalom és a szemantika struktúrájáról” szóló négy kötetével szembeállítva? Vagy végre éppen most van alaposan megerősítve a módszertan által? Kételkedhetünk előbbiben, mivel Luhmann rákényszerül, hogy a szociostrukturális fejlődésre támaszkodjon ahhoz, hogy képes legyen megalapozni a szociopolitikai szemantika jelentőségének elvesztését. E körforgásosság valószínúleg Luhmann társadalomelméletének gyenge pontja. Persze ez nem kerülte el Luhmann figyelmét sem, de az általa javasolt megoldások nem voltak különösen következetesek. Kezdve a körforgásosságnak, mint az elméletalkotás nélkülözhetetlen előfeltételének az elfogadásától - amelyet a hagyományos európai szemantika csak olyan metafizikai konstrukciók kisegítô megoldása révén tudott elkerülni, mint Isten, természet vagy ész - egészen addig az állításig nyúlnak megoldási javaslatai, hogy a szemantikai változások figyelembe vehetô távolságból lettek kitéve a strukturális változások hatásainak, amelynek következményeképpen a szemantika hirtelen megint abban a pozícióban van, hogy szóban ábrázoljon tényeket. De valóban igaz-e, hogy a társadalmi változás megelőzi a kognitív változást, vagy vannak olyan esetek is, ahol épp ennek az ellentétje igaz?

Luhmann úgy elemezte a hagyományos európai társdalom átalakulását modern társadalommá, hogy három dimenziót használt, amelyeknek társadalomelmélete ("A társadalom társadalma") három fô fejezetét szenteli: első a társadalmi dimenzió, amelyet Luhmann a kommunikáció és média dimenziójaként fog fel, és amelyet csak az Ego és az Alter közti megkülönböztetés alkot (szándékosan kerüli ki a személy és alany hagyományos európai szemantikáját); második az idôbeli dimenzió, amelyben a múlt és a jövő el van választva, és amelyet Luhmann evolúciónak nevez - határozottan nem fejlődés, mivel nincs vezetô médium a különböző médiumok közt, a társadalom funkcionális differenciálódásának pedig nincs vezetô rendszere; és végül a harmadik, tényeket tartalmazó dimenzió, amelyet Luhmann funkcionális megkülönböztetésként értelmez, és amelyben a rendszer és a környezet meghatározása foglalkoztat minket. Ezek azonban nem stabil környezetet alkotó megkülönböztetések, hanem inkább az érintett komponens rendszertôl, a tudománytól vagy a gazdaságtól, jogtól vagy oktatástól függnek. És ez a komponens rendszerek evolúciója során is változik.

Luhmann társadalomelméletében döntő az az állítás, hogy nincs egyetlen komponens rendszernek, például a politikának sem dominanciája a funkcionális megkü- 
lönböztetés dimenziójában; hogy a kommunikáció dimenziójában egyetlen domináns médium sem figyelhetô meg; továbbá, hogy a vezetô rendszerek és domináns média hiánya a modern társadalom meghatározó vonása. Ez is az oka annak, hogy a hagyományos európai szemantika miért nem képes többé megfelelően leírni egy modern társadalmat.

De vajon valóban elfogadható-e a mérték elvesztése, ahogy Luhmann leírja, a normák és értékek társadalmi kommunikációs formákra való átváltásának eredményeképpen? Sajnos Luhmann semmilyen ponton nem utal Michael Walzer koncepciójára az igazság szféráiról. Azon a koncepción belül az, amit Luhmann úgy határozott meg mint a modern társadalmak megfelelő önmeghatározása, az igazság úgy szerepel, mint állandóan elérendő norma, mint a jogosság mértéke, amelyet állandóan veszélyeztet Luhmann kifejezésével élve - a komponens rendszerek dominanciája.

S ez bezárja egy fő gondolatmenet körét, úgyhogy az, ami kezdetben ellentmondásnak tủnt - konkrétan, hogy egy dolog ugyanakkor valami más -, az úgy jelentkezik, mint a társadalom egy teljes elmélete, amely magában foglalja a reflexiót is saját társadalmi helyére, és a társadalmat ebben az értelemben egy ön-módosításra képes egységnek tekinti. Ha komolyan vesszük ezt a szigorúan intraszociális perspektívát, elfogadva, hogy bármelyik társadalomról szóló kommunikáció csak a társadalmon belül létezhet, akkor nincs helye a kritikai reflexiónak a társadalmon kívüli társadalomról, ahol a társadalom tárgyként tekinthető. A társadalmon belüli társadalomnak ez a meghatározása többé nem az alany koncepcióján alapul vagy a transzcendentális racionalitás szemszögéboól látszik. Ez magának a kommunikációnak tautologikus múvelete. A társadalom a társadalom formulája a társadalmi egység önmeghatározásához. Itt a szociológia egy hangsúlyos meghatározása ennek a különbségnek az egységét keresné annak érdekében, hogy megkülönböztesse az éppen adottat a lényegitôl. A társadalom egysége egy olyan társadalom lenne, amely eljutott önmagához, megfelelve ideáljának. A hagyomány fenntartotta erre a „felvilágosodás” címkét, és ezen igény mértékével mérte a létezô társadalmat. A felvilágosodás szociológiai magyarázatának el kell hagynia ezeket az igényeket, mivel ez a pozíció még most is megfigyelhetô, még ha csak a másodrendű megfigyelés szemszögébôl is. A világ esetlegessége nem fordítható meg ebben az értelemben, mert a szociológiai elmélet ahhoz a bizonyos dologhoz tartozik, amit elemez, vagyis a társadalomhoz.

Tehát a szociológia valódi jelentése az volna, hogy szabadon foglalkozhasson ezzel a fajta önmeghatározással annak érdekében, hogy az „újrameghatározás” folyamatában a megváltozott társadalmi strukturális viszonyokhoz igazítsa a hagyomány szemantikai örökségeit. Ez áthidalja a második legfőbb megkülönböztetést szemantika és társadalmi struktúra között. A modern társadalom funkcionális megkülönböztetés által generálja az önmegfigyelés kényszerét, és ezzel megváltoztatja az összes tematikai elemet. Ezáltal a posztmodernizmus ahhoz a ponthoz érkezik el, ahol a múlt jelenbeli meghatározások anyagává válik, amelyek az újrameghatározás által új formákat alkotnak, és így önmagukat állandósító konstrukciókká válnak. Mindazonáltal ez nem az elmúlt dolgokra való nosztalgikus visszatekintés kérdése, hanem inkább szemantikai tudatosság kérdése, amely állandóan megújítja önmagát. A döntô dolog a különbség, és nem egy mindent látó megfigyelő egysége. Ebben az értelemben Luhmann elmélete egy poszt-ontológiai elmélet, amely empirikus és múveleti módon halad, és amely még mindig szembesül a gyakorlat próbájával. 
Ugyanakkor megmarad a kérdés: Mennyire képez távolságot az alany koncepciójának kegyetlen dekonstrukciója és a helyébe állított ön-referens, zárt, autopoietikus rendszer koncepciója - amely többé nem különleges tárgy, hanem inkább a rendszer és környezet közti különbségnek tekintendố - a régi európai hagyománytól és ellentmondásaitól? Vajon a különbség kategóriájára fektetett hangsúly, mint kulcsfontosságú szociológiai koncepció, megfelelő reakció-e a szociológia végsô soron még mindig antropológiai konfigurációjának antinomiáira, mely egy feloldhatatlan alany alapvetố fogalmán alapul, és a humanitást, szubjektivitást és szabadságot használja végsô döntô orientációs elvként?

A további vita megmutatja majd, hogy az elméletben történt radikális elmozdulás az identitástól a különbség felé mennyire helyettesíti az egységben és totalitásban gondolkodó hagyományt. Helyébe állítja Luhmann a másodrendú megfigyelés elméletét, amely - szándéka szerint - megszüntet minden transzcendentális premisszát, és végső referenciákként meghatározások meghatározásait és megfigyelések megfigyeléseit állítja, amelyek eltörlik a kitüntetett álláspontokat és következményeket. Ebben az értelemben a szociológia önmagát kutatásként szervezi. A jelenlegi elméleti terv termékenységének még bizonyítania kell magát olyan szempontból, hogy mennyire segít nekünk átalakítani a hagyományos örökségeket eshetőségekre, hogy újrahasználhatóak legyenek mint „médium a rekonstrukció által szerzett új formák alakításához” (Luhmann, 1997: 1148). Ezen a ponton Luhmann kötve marad a régi európai hagyományhoz - csak a távolság foka vitatott még.

Luhmann visszatérít a szociológiához egy témát, amelyet majdnem feledésbe merült: a társadalomról szóló tudományos és reflektált vitát. Éppúgy, ahogy a biológia és a fizika nem csupán alapkoncepcióiktól függenek, a szociológia sem csak társadalomelmélet. Mindazonáltal, ha információval akar szolgálni alapjairól és társadalmi helyéről, nehezen kerülheti el a társadalomelméleti reflexiókat; már csak azért sem, mert társadalmi funkciójának folytán képes megfigyelni a reflexió minden korábbi formáját úgymint a vallást, filozófiát és tudományt.

Luhmann társadalomelmélete, érvelhetünk, egy utat kínál, amely a legújabb tudományos módszerek által és szigorúan elméleti alapon a modern társadalom gazdag elméletéhez vezet. Luhmann a szociológia számára kapcsolatokat tár fel más tudományokkal, és ez képessé teszi arra, hogy egy új kutatás áramlatát vezesse be elméletébe. A problémák két csoportja figyelhetô meg a társadalom elméletének keresésében. Elôször megkérdezhetjük, hogy osztjuk-e Luhmann meghatározását az elmélet intraszociális megalkotásából való következetes kiindulásról. Ez máris megold majd sok mindent. Másodszor felül kell vizsgálnunk megoldását, miszerint a társadalomelméletet mint társadalmi rendszerek elméletét tekinti, vagy helyettesíteni kell azt egy ésszerû alternatívával. Mivel mindenestre többé nem kell végső következtetéseket elérnünk, most már annak kérdése ez, hogy találunk-e használható folytatásokat, hiszen világos, hogy Luhmann után is lesz a társadalomnak szociológiai és egyéb meghatározása. A kérdés csupán az, hogy elérik-e az összetettség Luhmann munkájában felmutatott szintjét és mértékét, fốleg ami utolsó monográfiáját illeti. Ahogy Adorno modta: „A társadalomnak csak egy érett elmélete mondhatja meg, mi a társadalom.” Talán Luhmann megközelítése egy lépéssel közelebb vitt minket ehhez.

Váradi Kalmár Zsuzsanna fordítása 


\section{IRODALOM}

Luhmann, Niklas: Die Gesellschaft der Gesellschaft. 1. és 2. kötet. Frankfurt am Main,

\section{JAVASOLT OLVASMÁNYOK} Suhrkamp.

Luhmann, Niklas (1998): Observations on Modernity. (Megfigyelések a modernitásról.) Stanford, California, Stanford University Press.

Luhmann, Niklas(1995): Social Systems. (Társadalmi rendszerek.) Stanford, California, Stanford University Press.

Luhmann, Niklas (1993): Risk: A Sociological Theory. (Egy szociológiai elmélet.) New York, Aldine de Gruyter.

Luhmann, Niklas (1990): Essays on Self Reference. (Esszék az ön-referenciáról.) New York, Columbia University Press.

Luhmann, Niklas (1989): Ecological Communication. (Ökológiai kommunikáció.) Chicago, University of Chicago Press. 